\title{
Learning to Make Intelligent Decisions using an Expert System for the Intelligent Selection of Either PROMITHEE II or the Analytical Hierarchy Process
}

\author{
Malik Haddad, David Sanders, Nils Bausch, Giles Tewkesbury, Alexander Gegov, Mohamed Hassan \\ School of Engineering \\ University of Portsmouth, U.K. \\ malik.haddad@port.ac.uk,david.sanders@port.ac.uk,nils.bausch@prot.ac.uk, giles.tewkesbury@port.ac.uk, \\ alexander.gegov@port.ac.uk,mohamed.hassan@port.ac.uk
}

\begin{abstract}
This paper presents an expert system to select a most suitable discrete Multi-Criteria Decision Making (MCDM) method using an approach that analyses problem characteristics, MCDM methods characteristics, risk and uncertainty in inputs and applies sensitivity analysis to the inputs for a decisional problem. Outcomes of this approach can provide decision makers with a suggested candidate method that delivers a robust outcome. Numerical examples are presented where two MCDM methods are compared and one is recommended by calculating the minimum percentage change in criteria weights and performance measures required to alter the ranking of any two alternatives. A MCDM method will be recommended based on a best compromise in minimum percentage change required in inputs to alter the ranking of alternatives.
\end{abstract}

Keywords-Discrete; intelligent selection; problem characteristics; risk; robustness; uncertainty

\section{INTRODUCTION}

Different real-life problems require different decisionmaking techniques. Often, limited guidelines are provided to aid users to select an appropriate decision-making method. There is no method superior to another, but there is a method or a subset of methods more suitable to a specific type of decisional problem.

Multiple Criteria Decision Making (MCDM) methods are often considered as important and reliable techniques in decision making science. MCDM methods are a group of methods and techniques that allow decision makers to deal and integrate with predefined numerous and conflicting criteria to assess alternatives in order to reach a best compromise and feasible solution. Raju and Kumar defined MCDM as the process that enables decision makers to deal with conflicting real world quantitative and or qualitative multi-criteria problems, and to provide best-fit alternatives from a set of alternatives in certain, uncertain, or risky situations [1].

Since their development in the 1960s, MCDM methods have been criticized for many reasons, Olson, Mechitov and Moshkovich [2] claimed that MCDM methods outputs cannot be checked for accuracy since MCDM methods often have different aggregation algorithms and integrate input sets differently. Moreover, the authors in [2] stressed that it is difficult to compare different MCDM methods. Mutikanga [3] identified some further of criticisms:

- Different MCDM methods might provide different outcomes when applied to the same problem.

- Selecting a MCDM method from a set of methods might be considered a multi criteria problem. Many researchers referred to this problem as a "vicious cycle", they usually accept it as a multi-criteria problem but are against using a multi-criteria method for selection [4]-[6].

- Personal experience and other factors might influence and bias the decision process, especially when obtaining performance measures and criteria weights.

- Different methods use different aggregation procedures to obtain the overall score of alternatives. Important information might be lost due to a compensation between alternatives' good and poor performances on criteria.

Most humans are capable of working with a finite and small number of criteria at the same time [7]. To cope with multiple conflicting criteria problems, decision makers prefer to apply MCDM methods.

Risk and uncertainty could be sources of distortion in making decisions. Decision makers are encouraged to use more complex scientific decision-making techniques that are less vulnerable to distortion in such environments. MCDM methods might provide a good example of such techniques and could provide a suitable outcome.

Most real-life problems are associated with risk and uncertainty. Risk is an uncertain event that if it occurs, might have a positive or negative effect on the final outcome. For decision makers to provide more satisfactory outcomes, risk and uncertainty should be recognized and mitigated. Decision makers should avoid risks with negative impact, and exploit and enhance risks with positive impact [8]. Decisions should be revised and validated after each step of a decisional process. Invalid or inappropriate decisions should be reviewed. This feedback loop could enhance the decisional process and 
provide decision makers with a better vision of the impact of risk and uncertainty to the outcome.

Since different decision-making techniques have different advantages and disadvantages, the choice of method used has a significant importance to the final outcome. Applying different MCDM methods to the same decisional problem could generate different outcomes [9]. The use of an inappropriate MCDM method could lead to inappropriate decisions [10], [11]. This paper will explore a number of factors affecting the choice of MCDM methods, proposes a software tool to recommend a subset of candidate methods and conduct sensitivity analysis on inputs of decisional problems to recommend a method with the most robust outcome.

Many researchers identified the need for a MCDM selection expert system [4]-[6], [9]-[20], MacCrimmon [19] was probably the first to identify the significance of MCDM methods selection problems. He developed a tree diagram that included illustrative application examples to help potential users in identifying MCDM methods specifications and classifications

Roy and Slowinski [20] criticized other researchers attempts in comparing different MCDM methods based on their outcome and considered such comparisons as "ill founded", moreover authors in [20] preferred to view MCDM methods as tools for better understanding the decisional problem, exploring studying, and evaluating different possibilities, rather than considering MCDM methods as a tool for making decisions.

\section{FACTORS TO BE CONSIDERED}

Researchers [2], [4]-[6], [18] identified factors that affected the selection process: decision makers' previous knowledge and experience for a method, the availability of software tool to apply a method and ease of use and application. Considering the large number of MCDM methods available, several authors attempted to develop selection approaches, Ozernoy [10] stated that it is impossible to include all types of decisional problems, all existing MCDM methods, assumptions and preference information in one selection expert system.

Analysis of MCDM problems and methods exposed ten factors to be considered when developing a new expert system. These factors are:

Problem characteristics:

- Nature of alternative set:

- Continuous or discrete.

- Type of input set:

- Qualitative, quantitative, or mixed.

- Nature of information considered:

○ Deterministic, non-deterministic, or mixed.

- Type of decision problem addressed:

○ Choice, ranking, description, or sorting.
- Type of preference mode considered:

- Pairwise comparisons, performance measures.

MCDM methods characteristics:

- Type of ordering of alternatives:

- Total order, partial order, or interval.

- Criteria measure scale:

- Nominal, ordinal, absolute, or ratio.

- Type of preference structure considered.

- Preference, indifference, or incomparability.

- Availability of software tool to support method application.

- Ease of use that include: Ease of method understanding, user friendliness of software tool, previous experience and knowledge, and time needed to apply a method.

A novel MCDM expert system was developed using Visual Basic .net (Vb.net) programming language within Microsoft visual Studio (2012). A screen shot of the user interface is shown in Fig. 1.

The authors used Vb.net because of its ease of use, straight forward symbol set and relatively simple user interface.

\section{MCDM Methods Selection Sottware}

Problem Features

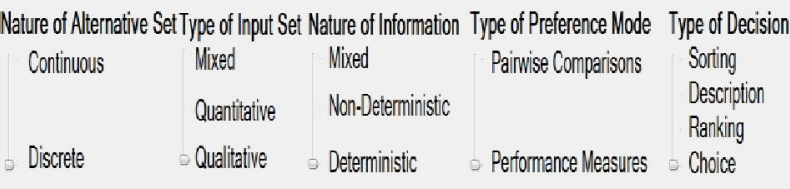

\section{Method Features}

Ordering of Alternatives Criteria Measure Scale Preference Structure Software Avaliability Ease of Use

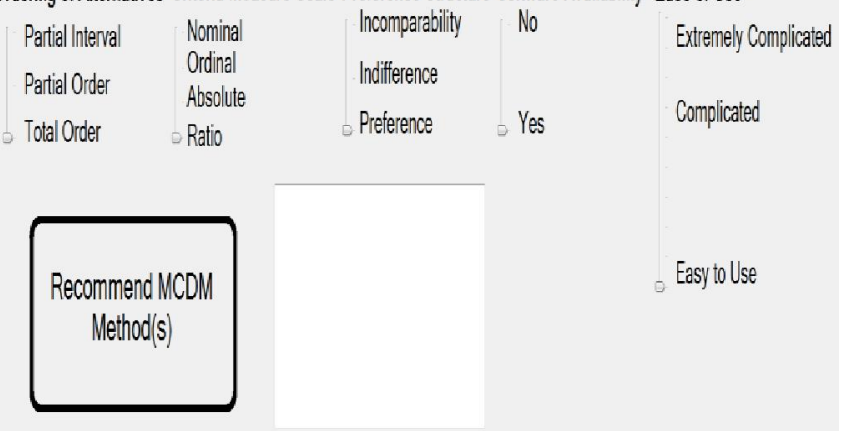

Fig. 1. New expert system user interface.

The expert system recommended a set of candidate methods to decision makers according to their answers to the 10 questions about factors mentioned earlier. Sensitivity analysis is conducted on the candidate methods to recommend a method that provided the most robust outcome and best suits the decisional problem. 


\section{NUMERICAL EXAMPLES}

This section describes two examples of applying sensitivity analysis to select the most suitable MCDM method from a subset of candidate methods. Numerical Example 1 used Voice of Customer, part I, Prioritizing Market Segment Preview Sample Decision from Expert Choice Sample Models [21]. Numerical Example 2 was randomly generated. For more numerical examples and applications of the new expert system please contact the authors at: Malik.haddad@port.ac.uk.

\section{A. Numerical Example 1}

This subsection considered a decisional problem proposed by Zultner [21] with a set of four criteria and four alternatives shown in Table I.

TABLE I. DECISION MATRIX FOR NUMERICAL EXAMPLE 1 [21]

\begin{tabular}{|l|l|l|l|l|}
\hline \multicolumn{1}{|c|}{ Criteria } & \multicolumn{1}{c|}{$\begin{array}{c}\mathbf{C}_{1}= \\
\mathbf{0 . 1 1 5}\end{array}$} & $\begin{array}{c}\mathbf{C}_{2}= \\
\mathbf{0 . 5 0 3}\end{array}$ & $\begin{array}{c}\mathbf{C}_{3}= \\
\mathbf{0 . 3 2 2}\end{array}$ & $\begin{array}{c}\mathbf{C}_{4}= \\
\mathbf{0 . 0 6 0}\end{array}$ \\
\hline $\mathrm{A}_{1}$ & 0.467 & 0.139 & 0.188 & 0.565 \\
\hline $\mathrm{A}_{2}$ & 0.067 & 0.101 & 0.063 & 0.262 \\
\hline $\mathrm{A}_{3}$ & 0.267 & 0.520 & 0.312 & 0.118 \\
\hline $\mathrm{A}_{4}$ & 0.200 & 0.240 & 0.437 & 0.055 \\
\hline
\end{tabular}

The expert system presented in this paper was applied, 10 questions addressing the factors mentioned in the previous section were asked as shown in Fig. 2. A screen shot of the expert system is shown in Fig. 3. Answers to these questions were:

- Nature of alternative set?

- Discrete.

- Type of input set?

$\circ$ Quantitative.

- Nature of information considered?

- Deterministic.

- Type of decision problem addressed?

○ Ranking.

- Type of preference mode considered?

- Pairwise comparisons.

- Type of ordering of alternatives?

- Total order.

- Criteria measure scale?

- Absolute.

- Type of preference structure considered.

$\circ \quad$ Preference.
Intelligent Systems Conference 2018 6-7 September 2018 | London, UK

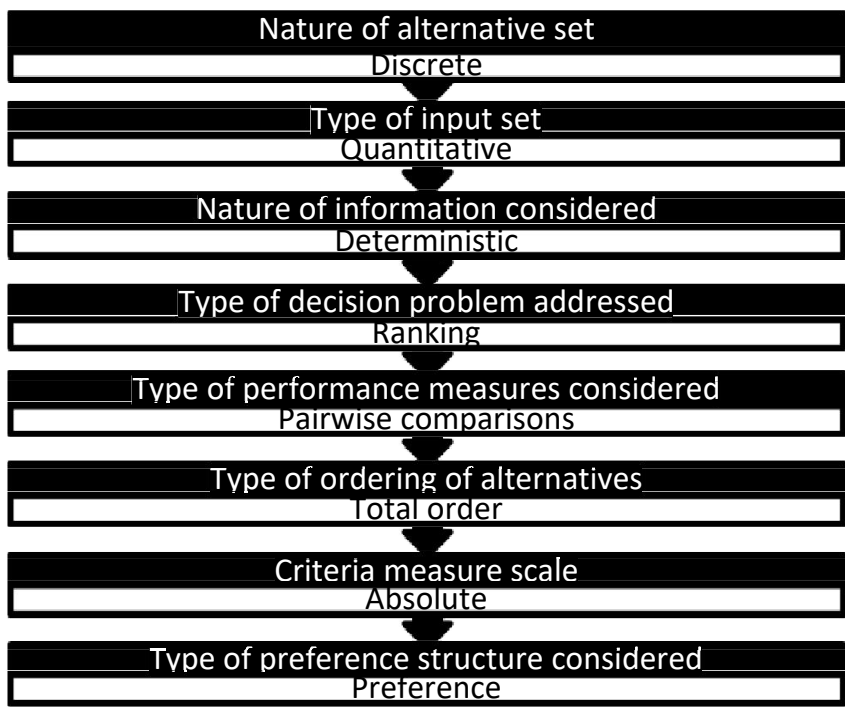

Fig. 2. Expert system branch for numerical Example 1.

\section{MCDM Methods Selection Software}

\section{Problem Features}

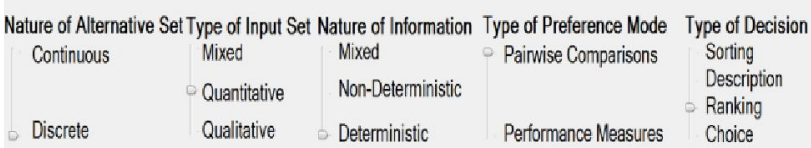

\section{Method Features}

Ordering of Alternatives Criteria Measure Scale Preference Structure Software Availability Ease of Use

\begin{tabular}{|c|c|c|c|c|}
\hline $\begin{array}{l}\text { Partial Interval } \\
\text { Partial Order } \\
\text { Total Order }\end{array}$ & $\begin{array}{l}\text { Nominal } \\
\text { Ordinal } \\
\text { Absolute } \\
\text { Ratio }\end{array}$ & $\begin{array}{l}\text { Incomparability } \\
\text { Indifference } \\
\text { Preference }\end{array}$ & Yes & $\begin{array}{l}\text { Extremely Complicated } \\
\text { Complicated }\end{array}$ \\
\hline \multicolumn{4}{|c|}{$\begin{array}{l}\text { AHP } \\
\text { BWM } \\
\text { PROMETHEE ॥ } \\
\text { ELECTRE III }\end{array}$} & Easy to Use \\
\hline
\end{tabular}

Fig. 3. Screen shot of the new expert system for numerical Example 1.

Candidate methods suggested by the expert system were:

- The Analytical Hierarchy Process (AHP)

- Best Worst Method (BWM)

- Preference Ranking Organization METHod for Enrichment Evaluations II (PROMETHEE II)

- Elimination Et Choix Traduisant la Realite III, (Elimination and Choice Expressing Reality III), (ELECTRE III) 
AHP and PROMETHE II were selected as examples from the group of candidate methods due to software availability and ease of use. AHP provided the following ranking of alternatives: $A_{3}>A_{4}>A_{1}>A_{2}$, with a global score of alternatives: $\mathrm{A}_{1}=0.218, \mathrm{~A}_{2}=0.092, \mathrm{~A}_{3}=0.394$ and $\mathrm{A}_{4}=$ 0.296. PROMETHEE II provided the same ranking of alternatives: $\mathrm{A}_{3}>\mathrm{A}_{4}>\mathrm{A}_{1}>\mathrm{A}_{2}$, with a net flow of alternatives: $\Phi\left(\mathrm{A}_{1}\right)=-0.100, \Phi\left(\mathrm{A}_{2}\right)=-0.920, \Phi\left(\mathrm{A}_{3}\right)=0.6287$ and $\Phi\left(\mathrm{A}_{4}\right)=$ 0.3913 .

AHP and PROMETHEE II methods delivered the same ranking of alternatives. Sensitivity analysis was conducted on both methods' outcomes to recommend a method that best suits this decisional problem and provided the most robust outcome. Minimum percentage change required to alter the ranking of alternatives for the most critical criterion weight and most critical performance measure was calculated. Results are shown in Tables II, III, IV and V.

The most critical criterion in this example using AHP was the second criterion $\left(\mathrm{C}_{2}\right)$, signified by the smallest value (bold number) in Table II. This value represented the minimum percentage change required in the weight of criterion two to change the ranking of alternatives three and four, where a $53.678 \%$ decrease in its weight changed the ranking of alternatives three and four $\left(\mathrm{A}_{4}>\mathrm{A}_{3}\right)$.

The most critical criterion in this example using PROMETHEE II was the second criterion $\left(\mathrm{C}_{2}\right)$, the smallest value (bold number) in Table III. This value represented the minimum percentage change required in the weight of criterion one to change the ranking of alternatives. Where a $56.262 \%$ decrease in its weight preferred alternative four to alternative three $\left(\mathrm{A}_{4}>\mathrm{A}_{3}\right)$.

TABLE II. Percentage ChANGe In CRITERIA WeIGHTS FOR NUMERICAL EXAMPLE 1 USING AHP

\begin{tabular}{|l|l|l|}
\hline Criteria & Percentage change & New Ranking \\
\hline$C_{1}$ & 176.521 & $\mathrm{~A}_{3}>\mathrm{A}_{1}>\mathrm{A}_{4}>\mathrm{A}_{2}$ \\
\hline $\mathrm{C}_{1}$ & 363.478 & $\mathrm{~A}_{1}>\mathrm{A}_{3}>\mathrm{A}_{4}>\mathrm{A}_{2}$ \\
\hline $\mathrm{C}_{2}$ & $\mathbf{- 5 3 . 6 7 8}$ & $\mathrm{A}_{4}>\mathrm{A}_{3}>\mathrm{A}_{1}>\mathrm{A}_{2}$ \\
\hline $\mathrm{C}_{2}$ & -86.481 & $\mathrm{~A}_{4}>\mathrm{A}_{1}>\mathrm{A}_{3}>\mathrm{A}_{2}$ \\
\hline $\mathrm{C}_{3}$ & -97.826 & $\mathrm{~A}_{3}>\mathrm{A}_{1}>\mathrm{A}_{4}>\mathrm{A}_{2}$ \\
\hline $\mathrm{C}_{3}$ & 93.789 & $\mathrm{~A}_{4}>\mathrm{A}_{3}>\mathrm{A}_{1}>\mathrm{A}_{2}$ \\
\hline $\mathrm{C}_{4}$ & 211.667 & $\mathrm{~A}_{3}>\mathrm{A}_{1}>\mathrm{A}_{4}>\mathrm{A}_{2}$ \\
\hline $\mathrm{C}_{4}$ & 446.667 & $\mathrm{~A}_{1}>\mathrm{A}_{3}>\mathrm{A}_{4}>\mathrm{A}_{2}$ \\
\hline $\mathrm{C}_{4}$ & 781.667 & $\mathrm{~A}_{1}>\mathrm{A}_{3}>\mathrm{A}_{2}>\mathrm{A}_{1}$ \\
\hline $\mathrm{C}_{4}$ & 1066.667 & $\mathrm{~A}_{1}>\mathrm{A}_{2}>\mathrm{A}_{3}>\mathrm{A}_{4}$ \\
\hline
\end{tabular}

TABLE III. PERCENTAGE CHANE IN CRITERIA WEIGHTS FOR NUMERICAL EXAMPLE 1 USING PROMETHEE II

\begin{tabular}{|l|l|l|}
\hline Criteria & Percentage change & New ranking \\
\hline$C_{1}$ & 213.043 & $\mathrm{~A}_{3}>\mathrm{A}_{1}>\mathrm{A}_{4}>\mathrm{A}_{2}$ \\
\hline $\mathrm{C}_{1}$ & 404.348 & $\mathrm{~A}_{1}>\mathrm{A}_{3}>\mathrm{A}_{4}>\mathrm{A}_{2}$ \\
\hline $\mathrm{C}_{2}$ & $\mathbf{- 5 6 . 2 6 2}$ & $\mathrm{A}_{4}>\mathrm{A}_{3}>\mathrm{A}_{1}>\mathrm{A}_{2}$ \\
\hline $\mathrm{C}_{3}$ & 58.385 & $\mathrm{~A}_{4}>\mathrm{A}_{3}>\mathrm{A}_{1}>\mathrm{A}_{2}$ \\
\hline $\mathrm{C}_{4}$ & 316.667 & $\mathrm{~A}_{3}>\mathrm{A}_{1}>\mathrm{A}_{4}>\mathrm{A}_{2}$ \\
\hline $\mathrm{C}_{4}$ & 566.667 & $\mathrm{~A}_{1}>\mathrm{A}_{3}>\mathrm{A}_{4}>\mathrm{A}_{2}$ \\
\hline $\mathrm{C}_{4}$ & 783.333 & $\mathrm{~A}_{1}>\mathrm{A}_{3}>\mathrm{A}_{2}>\mathrm{A}_{4}$ \\
\hline $\mathrm{C}_{4}$ & 1100 & $\mathrm{~A}_{1}>\mathrm{A}_{2}>\mathrm{A}_{3}>\mathrm{A}_{4}$ \\
\hline
\end{tabular}

TABle IV. Percentage Change In Performance Measures for NUMERICAL EXAMPLE 1 USING AHP

\begin{tabular}{|l|l|l|}
\hline $\begin{array}{l}\text { Performance } \\
\text { Measure }\end{array}$ & Percentage change & New ranking \\
\hline $\mathrm{A}_{1} \mathrm{C}_{1}$ & $\mathrm{~N} / \mathrm{F}$ & -- \\
\hline $\mathrm{A}_{2} \mathrm{C}_{1}$ & $\mathrm{~N} / \mathrm{F}$ & -- \\
\hline $\mathrm{A}_{3} \mathrm{C}_{1}$ & $\mathrm{~N} / \mathrm{F}$ & -- \\
\hline $\mathrm{A}_{4} \mathrm{C}_{1}$ & $\mathrm{~N} / \mathrm{F}$ & -- \\
\hline $\mathrm{A}_{1} \mathrm{C}_{2}$ & 90 & $\mathrm{~A}_{3}>\mathrm{A}_{1}>\mathrm{A}_{4}>\mathrm{A}_{2}$ \\
\hline $\mathrm{A}_{2} \mathrm{C}_{2}$ & $\mathrm{~N} / \mathrm{F}$ & -- \\
\hline $\mathrm{A}_{3} \mathrm{C}_{2}$ & $-\mathbf{3 0}$ & $\mathrm{A}_{4}>\mathrm{A}_{3}>\mathrm{A}_{1}>\mathrm{A}_{2}$ \\
\hline $\mathrm{A}_{4} \mathrm{C}_{2}$ & -65 & $\mathrm{~A}_{3}>\mathrm{A}_{1}>\mathrm{A}_{4}>\mathrm{A}_{2}$ \\
\hline $\mathrm{A}_{1} \mathrm{C}_{3}$ & 79 & $\mathrm{~A}_{3}>\mathrm{A}_{1}>\mathrm{A}_{4}>\mathrm{A}_{2}$ \\
\hline $\mathrm{A}_{2} \mathrm{C}_{3}$ & $\mathrm{~N} / \mathrm{F}$ & -- \\
\hline $\mathrm{A}_{3} \mathrm{C}_{3}$ & -84 & $\mathrm{~A}_{4}>\mathrm{A}_{3}>\mathrm{A}_{1}>\mathrm{A}_{2}$ \\
\hline $\mathrm{A}_{4} \mathrm{C}_{3}$ & -39 & $\mathrm{~A}_{3}>\mathrm{A}_{1}>\mathrm{A}_{4}>\mathrm{A}_{2}$ \\
\hline $\mathrm{A}_{4} \mathrm{C}_{3}$ & $\mathrm{~A}$ & $\mathrm{~A}_{4}>\mathrm{A}_{3}>\mathrm{A}_{1}>\mathrm{A}_{2}$ \\
\hline $\mathrm{A}_{1} \mathrm{C}_{4}$ & $\mathrm{~N} / \mathrm{F}$ & -- \\
\hline $\mathrm{A}_{2} \mathrm{C}_{4}$ & $\mathrm{~N} / \mathrm{F}$ & -- \\
\hline $\mathrm{A}_{3} \mathrm{C}_{4}$ & $\mathrm{~N} / \mathrm{F}$ & -- \\
\hline $\mathrm{A}_{4} \mathrm{C}_{4}$ & $\mathrm{~N} / \mathrm{F}$ & -- \\
\hline
\end{tabular}

The most critical performance measure in this example using AHP was $\left(\mathrm{A}_{3} \mathrm{C}_{2}\right)$, the smallest value (bold number) in Table IV. This value represented the minimum percentage change required in the performance measure $\left(\mathrm{A}_{3} \mathrm{C}_{2}\right)$ to change the ranking of alternatives three and four $\left(\mathrm{A}_{3} \& \mathrm{~A}_{4}\right)$, where a $30 \%$ decrease its value changed the ranking of alternatives three and four $\left(\mathrm{A}_{4}>\mathrm{A}_{3}\right)$.

The most critical performance measures in this example using PROMETHEE II were $\left(\mathrm{A}_{3} \mathrm{C}_{2}\right)$ and $\left(\mathrm{A}_{4} \mathrm{C}_{2}\right)$, identified by the smallest values (bold numbers) in Table $\mathrm{V}$. These values represented the minimum change required in the performance measure $\left(\mathrm{A}_{3} \mathrm{C}_{2}\right)$ to change the ranking of alternative three and four, where a $36 \%$ decrease its value made alternative four preferred to alternative three $\left(\mathrm{A}_{4}>\mathrm{A}_{3}\right)$, and the minimum percentage change required in the performance measure $\left(\mathrm{A}_{4} \mathrm{C}_{2}\right)$ to change the ranking of alternative one and four, where a $36 \%$ decrease in its value made alternative one preferred to alternative four $\left(\mathrm{A}_{1}>\mathrm{A}_{4}\right)$. N/F shown in Tables IV and $\mathrm{V}$ stands for a non-feasible value.

TABLE V. PERCENTAge CHANGE IN PERFormance MEASURES FOR NUMERICAL EXAMPLE 1 USING PROMETHEE II

\begin{tabular}{|l|l|l|}
\hline $\begin{array}{l}\text { Performance } \\
\text { Measure }\end{array}$ & Percentage change & New ranking \\
\hline $\mathrm{A}_{1} \mathrm{C}_{1}$ & $\mathrm{~N} / \mathrm{F}$ & -- \\
\hline $\mathrm{A}_{2} \mathrm{C}_{1}$ & $\mathrm{~N} / \mathrm{F}$ & -- \\
\hline $\mathrm{A}_{3} \mathrm{C}_{1}$ & $\mathrm{~N} / \mathrm{F}$ & -- \\
\hline $\mathrm{A}_{4} \mathrm{C}_{1}$ & $\mathrm{~N} / \mathrm{F}$ & -- \\
\hline $\mathrm{A}_{1} \mathrm{C}_{2}$ & 57 & $\mathrm{~A}_{3}>\mathrm{A}_{1}>\mathrm{A}_{4}>\mathrm{A}_{2}$ \\
\hline $\mathrm{A}_{2} \mathrm{C}_{2}$ & $\mathrm{~N} / \mathrm{F}$ & -- \\
\hline $\mathrm{A}_{3} \mathrm{C}_{2}$ & -36 & $\mathrm{~A}_{4}>\mathrm{A}_{3}>\mathrm{A}_{1}>\mathrm{A}_{2}$ \\
\hline $\mathrm{A}_{3} \mathrm{C}_{2}$ & -57 & $\mathrm{~A}_{4}>\mathrm{A}_{1}>\mathrm{A}_{3}>\mathrm{A}_{2}$ \\
\hline $\mathrm{A}_{4} \mathrm{C}_{2}$ & -36 & $\mathrm{~A}_{3}>\mathrm{A}_{1}>\mathrm{A}_{4}>\mathrm{A}_{2}$ \\
\hline $\mathrm{A}_{4} \mathrm{C}_{2}$ & -70 & $\mathrm{~A}_{4}>\mathrm{A}_{3}>\mathrm{A}_{1}>\mathrm{A}_{2}$ \\
\hline $\mathrm{A}_{1} \mathrm{C}_{3}$ & 87 & $\mathrm{~A}_{3}>\mathrm{A}_{1}>\mathrm{A}_{4}>\mathrm{A}_{2}$ \\
\hline $\mathrm{A}_{2} \mathrm{C}_{3}$ & $\mathrm{~N} / \mathrm{F}$ & -- \\
\hline $\mathrm{A}_{3} \mathrm{C}_{3}$ & -74 & $\mathrm{~A}_{4}>\mathrm{A}_{3}>\mathrm{A}_{1}>\mathrm{A}_{2}$ \\
\hline $\mathrm{A}_{4} \mathrm{C}_{3}$ & -43 & $\mathrm{~A}_{3}>\mathrm{A}_{1}>\mathrm{A}_{4}>\mathrm{A}_{2}$ \\
\hline $\mathrm{A}_{1} \mathrm{C}_{4}$ & $\mathrm{~N} / \mathrm{F}$ & -- \\
\hline $\mathrm{A}_{2} \mathrm{C}_{4}$ & $\mathrm{~N} / \mathrm{F}$ & -- \\
\hline $\mathrm{A}_{3} \mathrm{C}_{4}$ & $\mathrm{~N} / \mathrm{F}$ & -- \\
\hline $\mathrm{A}_{4} \mathrm{C}_{4}$ & $\mathrm{~N} / \mathrm{F}$ & -- \\
\hline
\end{tabular}


TABLE VI. DECISION MATRIX FOR NUMERICAL EXAMPLE 2

\begin{tabular}{|l|l|l|l|}
\hline \multicolumn{1}{|c|}{ Criteria } & \multicolumn{1}{|c|}{$\mathbf{C}_{\mathbf{1}}=\mathbf{0 . 6 0 0}$} & $\mathbf{C}_{\mathbf{2}}=\mathbf{0 . 3 0 0}$ & $\mathbf{C}_{\mathbf{3}}=\mathbf{0 . 1 0 0}$ \\
\hline $\mathrm{A}_{1}$ & 0.500 & 0.130 & 0.270 \\
\hline $\mathrm{A}_{2}$ & 0.380 & 0.390 & 0.500 \\
\hline $\mathrm{A}_{3}$ & 0.120 & 0.480 & 0.230 \\
\hline
\end{tabular}

\section{B. Numerical Example 2}

This subsection considered a decisional problem with a set of three criteria and three alternatives shown in Table VI. The expert system presented in this paper was applied as shown in Fig. 2. A screen shot of the expert system is shown in Fig. 3. Answers to the 10 questions addressing the factors mentioned in the previous section were the same as the previous numerical example.

Candidate methods suggested by the expert system were:

- AHP

- BWM

- PROMETHEE II

- ELECTREE III

AHP and PROMETHE II methods were selected from the group of candidate methods due to software availability and ease of use. AHP provided the following ranking: $A_{2}>A_{1}>$ $\mathrm{A}_{3}$, with a global score of alternatives: $\mathrm{A}_{1}=0.363, \mathrm{~A}_{2}=0.395$ and $\mathrm{A}_{3}=0.242$. PROMETHEE II provided the following ranking: $A_{1}>A_{2}>A_{3}$, with a net flow of alternatives: $\Phi\left(A_{1}\right)=$ $0.300, \Phi\left(\mathrm{A}_{2}\right)=0.100, \Phi\left(\mathrm{A}_{3}\right)=-0.400$.

AHP and PROMETHEE II methods delivered different ranking for alternatives. Sensitivity analysis was conducted on both methods' outcomes to recommend a method that best suits this decisional problem and provided the most robust outcome. Minimum percentage change required to alter the ranking of alternatives for the most critical criterion weight and most critical performance measure was calculated. Results are shown in Tables VII, VIII, IX and X.

The most critical criterion in this example using AHP was the first criterion $\left(\mathrm{C}_{1}\right)$, signified by the smallest value (bold number) in Table VII. This value represented the minimum percentage change required in the weight of criterion one to change the ranking of alternatives one and two, where a $14.333 \%$ increase in its weight changed the ranking of alternatives one and two $\left(\mathrm{A}_{1}>\mathrm{A}_{2}\right)$.

TABLE VII. Percentage Change In CRiteria Weights for Numerical EXAMPLE 2 USING AHP

\begin{tabular}{|l|l|l|}
\hline Criteria & Percentage change & New Ranking \\
\hline$C_{1}$ & -95.333 & $A_{3}>A_{2}>A_{1}$ \\
\hline$C_{1}$ & -31.667 & $A_{2}>A_{3}>A_{1}$ \\
\hline$C_{1}$ & $\mathbf{1 4 . 3 3 3}$ & $A_{1}>A_{2}>A_{3}$ \\
\hline$C_{2}$ & -33.667 & $A_{1}>A_{2}>A_{3}$ \\
\hline$C_{2}$ & 60.667 & $A_{2}>A_{3}>A_{1}$ \\
\hline$C_{2}$ & 147.667 & $A_{3}>A_{2}>A_{1}$ \\
\hline$C_{3}$ & N/F & -- \\
\hline
\end{tabular}

TABLE VIII. PERCENTAGE CHANE IN CRITERIA WEIGHTS FOR NUMERICAL EXAMPLE 2 USING PROMETHEE II

\begin{tabular}{|l|l|l|}
\hline Criteria & Percentage change & New ranking \\
\hline$C_{1}$ & $\mathbf{- 1 8 . 3 3 3}$ & $A_{2}>A_{1}>A_{3}$ \\
\hline$C_{1}$ & -36.667 & $A_{2}>A_{3}>A_{1}$ \\
\hline$C_{1}$ & -68.333 & $A_{3}>A_{2}>A_{1}$ \\
\hline$C_{2}$ & 40 & $A_{2}>A_{1}>A_{3}$ \\
\hline$C_{2}$ & 63.333 & $A_{2}>A_{3}>A_{1}$ \\
\hline$C_{2}$ & 80 & $A_{3}>A_{2}>A_{1}$ \\
\hline$C_{3}$ & 160 & $A_{2}>A_{1}>A_{3}$ \\
\hline
\end{tabular}

The most critical criterion in this example using PROMETHEE II was the first criterion $\left(\mathrm{C}_{1}\right)$, the smallest value (bold number) in Table VIII. This value represented the minimum percentage change required in the weight of criterion one to change the ranking of alternatives. Where a $18.333 \%$ decrease in its weight preferred alternative two to alternative one $\left(A_{2}>A_{1}\right)$.

The most critical performance measure in this example using AHP was $\left(\mathrm{A}_{1} \mathrm{C}_{1}\right)$, the smallest value (bold number) in Table IX. This value represented the minimum percentage change required in the performance measure $\left(\mathrm{A}_{1} \mathrm{C}_{1}\right)$ to change the ranking of alternatives one and two $\left(\mathrm{A}_{1} \& \mathrm{~A}_{2}\right)$, where an $8 \%$ increase in its value changed the ranking of alternatives one and two $\left(A_{2}>A_{1}\right)$. N/F shown in Tables IX and $X$ stands for a non-feasible value.

The most critical performance measures in this example using PROMETHEE II was $\left(\mathrm{A}_{3} \mathrm{C}_{2}\right)$, identified by the smallest values (bold numbers) in Table $\mathrm{X}$. This value represented the minimum change required in the performance measure $\left(\mathrm{A}_{3} \mathrm{C}_{2}\right)$ to change the ranking of alternative one and two, where a $11 \%$ decrease in its value made alternative two preferred to alternative one $\left(A_{2}>A_{1}\right)$.

TABle IX. Percentage Change in Performance Measures for NUMERICAL EXAMPLE 2 USING AHP

\begin{tabular}{|l|l|l|}
\hline $\begin{array}{l}\text { Performance } \\
\text { Measure }\end{array}$ & Percentage change & New ranking \\
\hline $\mathrm{A}_{1} \mathrm{C}_{1}$ & $\mathbf{8}$ & $\mathrm{A}_{1}>\mathrm{A}_{2}>\mathrm{A}_{3}$ \\
\hline $\mathrm{A}_{1} \mathrm{C}_{1}$ & -33 & $\mathrm{~A}_{2}>\mathrm{A}_{3}>\mathrm{A}_{1}$ \\
\hline $\mathrm{A}_{2} \mathrm{C}_{1}$ & -10 & $\mathrm{~A}_{1}>\mathrm{A}_{2}>\mathrm{A}_{3}$ \\
\hline $\mathrm{A}_{2} \mathrm{C}_{1}$ & -57 & $\mathrm{~A}_{1}>\mathrm{A}_{3}>\mathrm{A}_{2}$ \\
\hline $\mathrm{A}_{3} \mathrm{C}_{1}$ & $\mathrm{~N} / \mathrm{F}$ & -- \\
\hline $\mathrm{A}_{1} \mathrm{C}_{2}$ & 64 & $\mathrm{~A}_{1}>\mathrm{A}_{2}>\mathrm{A}_{3}$ \\
\hline $\mathrm{A}_{2} \mathrm{C}_{2}$ & -19 & $\mathrm{~A}_{1}>\mathrm{A}_{2}>\mathrm{A}_{3}$ \\
\hline $\mathrm{A}_{3} \mathrm{C}_{2}$ & 27 & $\mathrm{~A}_{1}>\mathrm{A}_{2}>\mathrm{A}_{3}$ \\
\hline $\mathrm{A}_{1} \mathrm{C}_{3}$ & 71 & $\mathrm{~A}_{1}>\mathrm{A}_{2}>\mathrm{A}_{3}$ \\
\hline $\mathrm{A}_{2} \mathrm{C}_{3}$ & -39 & $\mathrm{~A}_{1}>\mathrm{A}_{2}>\mathrm{A}_{3}$ \\
\hline $\mathrm{A}_{3} \mathrm{C}_{3}$ & $\mathrm{~N} / \mathrm{F}$ & -- \\
\hline
\end{tabular}


TABlE X. Percentage Change in Performance Measures For NUMERICAL EXAMPLE 2 USING PROMETHEE II

\begin{tabular}{|l|l|l|}
\hline $\begin{array}{l}\text { Performance } \\
\text { Measure }\end{array}$ & Percentage change & New ranking \\
\hline $\mathrm{A}_{1} \mathrm{C}_{1}$ & -14 & $\mathrm{~A}_{2}>\mathrm{A}_{1}>\mathrm{A}_{3}$ \\
\hline $\mathrm{A}_{1} \mathrm{C}_{1}$ & -62 & $\mathrm{~A}_{2}>\mathrm{A}_{3}>\mathrm{A}_{1}$ \\
\hline $\mathrm{A}_{2} \mathrm{C}_{1}$ & 18 & $\mathrm{~A}_{2}>\mathrm{A}_{1}>\mathrm{A}_{3}$ \\
\hline $\mathrm{A}_{2} \mathrm{C}_{1}$ & -58 & $\mathrm{~A}_{1}>\mathrm{A}_{3}>\mathrm{A}_{2}$ \\
\hline $\mathrm{A}_{3} \mathrm{C}_{1}$ & $\mathrm{~N} / \mathrm{F}$ & -- \\
\hline $\mathrm{A}_{1} \mathrm{C}_{2}$ & $\mathrm{~N} / \mathrm{F}$ & -- \\
\hline $\mathrm{A}_{2} \mathrm{C}_{2}$ & 13 & $\mathrm{~A}_{2}>\mathrm{A}_{1}>\mathrm{A}_{3}$ \\
\hline $\mathrm{A}_{3} \mathrm{C}_{2}$ & -11 & $\mathrm{~A}_{2}>\mathrm{A}_{1}>\mathrm{A}_{3}$ \\
\hline $\mathrm{A}_{1} \mathrm{C}_{3}$ & $\mathrm{~N} / \mathrm{F}$ & -- \\
\hline $\mathrm{A}_{2} \mathrm{C}_{3}$ & $\mathrm{~N} / \mathrm{F}$ & -- \\
\hline $\mathrm{A}_{3} \mathrm{C}_{3}$ & $\mathrm{~N} / \mathrm{F}$ & -- \\
\hline
\end{tabular}

\section{DISCUSSION}

This paper applied different MCDM methods to the same decisional problems and the results showed that different MCDM methods might deliver different outcomes. They had different sensitivity towards changes in inputs (i.e. risk and uncertainty), because different methods treat performance measures and criteria weights differently. Criteria weights and performance measures often have different impacts on the final outcome [22]. Hobbs [11] claimed that when two MCDM methods delivered considerably different outcomes then, at least one method is invalid.

When risk and uncertainty are expected to affect criteria weights, then a method that is least vulnerable to fluctuations to criteria weights should be recommended to the decisional problem.

Example 1 showed that AHP required a 53.678\% decrease to the most critical criterion weight to alter the ranking of alternatives, while PROMETHEE II required a 56.262\% decrease to the most critical criterion weight to alter the ranking of alternatives. Both methods delivered the same outcomes, but AHP was 1.048 times more sensitive to fluctuations in the most critical criterion weight than PROMETHEE II. Thus, PROMETHEE II was recommended for that decisional problem.

Example 2 showed that AHP required a $14.333 \%$ increase to the most critical criterion weight to alter the ranking of alternatives, while PROMETHEE II required an 18.333\% decrease to the most critical criterion weight to alter the ranking of alternatives. Both methods delivered different outcomes. AHP was 1.279 times more sensitive to fluctuations in the most critical criterion weight than PROMETHEE II. Thus, PROMETHEE II was recommended for that decisional problem.

When risk and uncertainty are expected to affect performance measures, then, a method that is least vulnerable to fluctuations to performance measures would be recommended for the decisional problem.

Example 1 showed that AHP required a $30 \%$ decrease to the most critical performance measure score to alter the ranking of alternatives, while PROMETHEE II required a 36\% decrease to the most critical performance measure score to alter the ranking of alternatives. AHP was 1.2 times more sensitive to fluctuations in most critical performance measure than
PROMETHEE II. Thus, the expert system recommended PROMETHEE II for this decisional problem.

Example 2 showed that AHP required an $8 \%$ increase to the most critical performance measure score to alter the ranking of alternatives, while PROMETHEE II required an 11\% decrease to the most critical performance measure score to alter the ranking of alternatives. AHP was 1.375 times more sensitive to fluctuations in the most critical performance measure than PROMETHEE II. Thus, the expert system recommended PROMETHEE II for this decisional problem.

When risk and uncertainty are expected to affect both criteria weights and performance measures then a method that is least vulnerable to fluctuations in criteria weights and performance measures should be recommended to the decisional problem. In some cases, a compromise between these factors is recommended.

Example 1 showed that both methods delivered relatively robust outcomes. AHP was more vulnerable than PROMETHEE II to fluctuations in both criteria weights and performance measures. Recommending PROMETHEE II to that decisional problem would provide a more robust outcome with less vulnerability to risk and uncertainty.

Example 2 showed that both methods delivered different outcomes. Both methods were relatively vulnerable to fluctuations in both criteria weights and performance measures. AHP was more vulnerable than PROMETHEE II to fluctuations in both criteria weights and performance measures. Recommending PROMETHEE II for that decisional problem provided a more robust outcome with less vulnerability to risk and uncertainty.

\section{CONCLUSIONS}

Due to the large number of existing MCDM methods, potential users are encouraged to learn more about MCDM methods and problem characteristics to select the method that best suits their decisional problem, and avoid potential user's dissatisfaction.

This paper proposed an expert system to recommend a MCDM method from a subset of candidate methods based on the sensitivity of output to changes in input.

The authors are not suggesting that one MCDM method is better than another, but one MCDM method delivers a more robust outcome than another for a specific decisional problem. Risk and uncertainty to inputs (i.e. performance measures and criteria weights) should be analyzed when recommending a MCDM method for a specific problem. Sensitivity analysis should be conducted on performance measures and criteria weights to give a best compromise recommendation.

The decision-making methods will now be applied to some real-world engineering problems [23]-[30].

\section{REFERENCES}

[1] K. S. Raju and D. N. Kumar, "Irrigation Planning using Genetic Algorithms," Water Resource Management, vol. 18, pp. 163 - 176, 2004.

[2] D. L. Olson, A. Mechitov and H. Moshkovich, Learning aspects of decision aids," in Proc. 15th Int. Conf. on MCDM'00, IEEE Symposium 
on Computational Intelligence in Multicriteria Decision Making (MCDM 2007), Ankara, Turkey, 2007.

[3] H. E. Mutikanga, "Water Loss Management, Tools and Methods for developing countries," Ph.D. dissertation, Eng. Delft Uni, Delft, Netherlands, 2012

[4] E Kornyshova and C Salinesi, "MCDM Techniques Selection Approaches: State of the Art," in Proc. Of the 2007 IEEE Symposium on Computational Intelligence in Multicriteria Decision Making (MCDM 2007), 2007.

[5] A. Laaribi, "SIG et analyse multicitere," Paris, France, Hermes Science Publications, 2000.

[6] F. Ulengin, Y. I. Topcu and S. O. Sahin, "An artificial neural network approach to multicriteria method selection," in Proc. Of 15th Int. Conf. on MCDM'00, IEEE Symposium on Computational Intelligence in Multicriteria Decision Making (MCDM 2007), Ankara, Turkey, 2007.

[7] G. A. Miller, "The magical number seven, plus or minus two: Some limits on our capacity for processing information," Psychological Review, vol. 21, pp. $81-97,1956$.

[8] Project Management Institute, "Risk Management Plan," in "A guide to the project management body of knowledge (PMBOK)," 6th ed Newtown Square, Pa, USA, PMI, 2004.

[9] K. A. Eldarandaly, A. N. Ahmed and N. M. AbdelAziz, "An Expert System for Choosing the Suitable MCDM Method for Solving a Spatial Decision Problem," in Proc. 9th Int. Conf. on Production Engineering, Design and Control, Alexandria, Egypt, 10-12 February, 2009.

[10] V. M. Ozernoy, "Choosing the Best Multiple Criteria Decision Making Method,"INFOR, vol. 30, no. 2, pp. 159 - 171, 1992.

[11] B. F. Hobbs, "What can We Learn from Experiments in Multi-objective Decision Analysis?," IEEE Trans. Systems, Man, Cybernetics, vol. 16, no. 3, pp. 384-394, 1986.

[12] T. L. Saaty and D. Ergu, "When is a Decision Making Method Trustworthy? Criteria for Evaluating Multi-Criteria Decision Making Methods, "International Journal of Information Technology \& Decision Making, vol. 14, no. 6, 2015. DOI: 10.1141/S021962201550025X

[13] E. Ballestero and C. Romero, Multiple criteria decision making and its applications to economic problems, Netherlands, Kluwer Academic Publishers, 1998.

[14] P. Mota, "Comparative Analysis of Multicriteria Decision Making Methods," Ph.D. dissertation, Elec. and Comp. Eng. Uni. Nova De Lisboa, Lisbon, Porugal, 2013.

[15] M. Grenshon, "Model choice in multi-objective decision making in natural resources systems," Ph.D. dissertation, Sys. And Ind. Eng. U.A., Arizona, Ar., USA, 1981.

[16] P. Vincke, "A short note on a methodology for choosing a decision-aid method, Advances in Multicriteria Analysis, "Edited by P. M. Pardalos, Y. Siskos and C. Zopoundis, Kluwer Academic Publishers, Netherlands, pp. 3-7, 1995.

[17] A. Guitouni and J. M. Martel, "Tentative guidelines to help choosing an appropriate MCDM method," European Journal of Operational Research, vol. 109, pp. 501-521, 1997.
[18] T. Hanne, "Meta Decision Problems in Multiple Criteria Decision Making" in "Multiple Criteria Decision Making-Advances in MCDM Model, Algorithms, Theory and Applications," Springer (Kluwer), vol. 21, 1999.

[19] K. R. MacCrimmon, "An Overview of the multiple objective decision making," in Multiple Criteria Decision Making" Columbia, South Carolina, USA, The University of South Carolina Press, 1973.

[20] B. Roy and R. Slowinski, "Questions guiding the choice of a multicriteria decision aiding method," Euro J. Decis. Process, vol. 1 pp. 69-97, 2013

[21] Expert Choice Sample Model, "Voice of customer, Part I, Prioritizing Market Segements," 2004, Expert Choice, from Zultner, R. "Prioritization of restaurant services as a function of how well they contribute to each of their maket segments," Decision by Objectives, pp. 340 - 344, Princeton, N.J. USA, 1991.

[22] F. Tscheikner-Gratl, P. Egger, W. Rauch and M. Kleidorfer, "Comparison of Multi-Criteria Decision Support Methods for Integrated Rehabilitation Prioritization," Water, vol. 9, no. 68, 2017.

[23] D.A. Sanders, A. Gegov, M. Haddad, F. Ikwan, D. Wiltshire and Y. C. Tan "A Rule-based Expert System to decide on direction and speed of a powered wheelchair". IEEE Proceedings of the SAI Conference on Intelligent Systems 2018 (In Press).

[24] Sanders, DA \& Bausch, NC "Improving steering of a powered wheelchair using an expert system to interpret hand tremor". in H Liu, N Kubota, X Zhu, R Dillmann \& D Zhou (eds), Intelligent robotics and applications: Part II. Lecture notes in artificial intelligence, vol. 9245, Springer, Switzerland, pp. 460-471. 2015.

[25] D. Sanders, A. Gegov, G. E. Tewkesbury and R. Khusainov "Sharing driving between a vehicle driver and.a sensor system using trust-factors to set control gains. IEEE Proceedings of the SAI Conference on Intelligent Systems 2018 (In Press).

[26] Sanders, D 2017, 'New method to design large scale high-recirculation airlift reactors', Proc of Inst of Civil Eng; Journal of Environmental Engineering and Science, vol 12, no. 3, pp. 62-78. 2017.

[27] D. Sanders, D. C. Robinson, M. Hassan, M. Haddad, A. Gegov and N. Ahmed "Making decisions about saving energy in Compressed Air Systems using Ambient Intelligence and AI". IEEE Proceedings of the SAI Conference on Intelligent Systems 2018 (In Press).

[28] D.A. Sanders, 'Using self-reliance factors to decide how to share control between human powered wheelchair drivers and ultrasonic sensors' IEEE Transactions on Neural Systems and Rehabilitation Engineering, vol 25, no. 8, pp. 1221-1229. DOI: 10.1109/TNSRE.2016.2620988. 2017.

[29] D. Sanders, Q. Wang, N. Bausch, Y. Huang, S. Khaustov and I. Popov "An efficient method to produce minimal real time geometric representations of moving obstacles". IEEE Proceedings of the SAI Conference on Intelligent Systems 2018 (In Press).

[30] D.A. Sanders, Sanders, H, Gegov, A \& Ndzi, D 2017, Rule-based system to assist a tele-operator with driving a mobile robot. in $\mathrm{Y} \mathrm{Bi}, \mathrm{S}$ Kapoor \& R Bhatia (eds), SAI Intelligent Systems (IntelliSys) vol. 2, Lecture Notes in Networks and Systems, vol. 16, Springer, pp. 599-615, DOI: 10.1007\%2F978-3-319-56991-8 44. 2017. 